fendant will have something to offer." Fitch arose and said, "No, no, Your Honor. I had my say to the jury, now let nature take its course, let nature take its course." Fitch had the friendship of every man that he was acquainted with at the Polk county bar and upon his death, which occurred in comparatively recent years, the expressions of regret among the legal fraternity were as numerous and as sincere as with any lawyer who has passed from the realm of life into the Great Beyond during the period of my years in the practice in this community.

This review has already covered a wide field and has occupied more time than probably you members of the bar can well afford to give on this occasion, but in closing I want to leave with you this thought, that on this occasion, wherein we have refreshed our minds and our recollections of the historical figures who have come and gone in the practice of law in this community; and as we call up in our mind's eye a picture of these men of brilliant attainments and accomplishments in their chosen profession and who have gone to their final reward, that we resolve that in so far as it lies in our power, we will emulate their example, so that it may be truthfully said of us when we answer the final summons what can be truthfully said of them, "They were great men and great lawyers."

\title{
CHIEF POWESHIEK AT DES MOINES
}

The treaty of 1842, made by Gov. John Chambers at Agency, for the cession of the Des Moines river valley, was signed by chiefs of the Foxes and chiefs of the Sacs separately, in all forty-four in number; and heading the list on behalf of the Foxes was the name of "Pow a shick", as it was spelled in that document. He had also signed the treaty of 1836, made by Gov. Henry Dodge, for cession of the "Keokuk Reserve." $\mathrm{He}$ had signed the treaty of 1832, with Gen. Winfield Scott for the first "Black Hawk Purchase." The first of the chiefs of the Foxes signing the treaty of 1825 , arranged by Gen. Lewis Cass, was "Ti-a-mah". Powesheik is credited with having greater influence than any other in preventing the war started by Black Hawk becoming general, and he refused to join in the hostilities and was followed by Chief Keokuk. He was of the ruling Bear clan of the Foxes. 


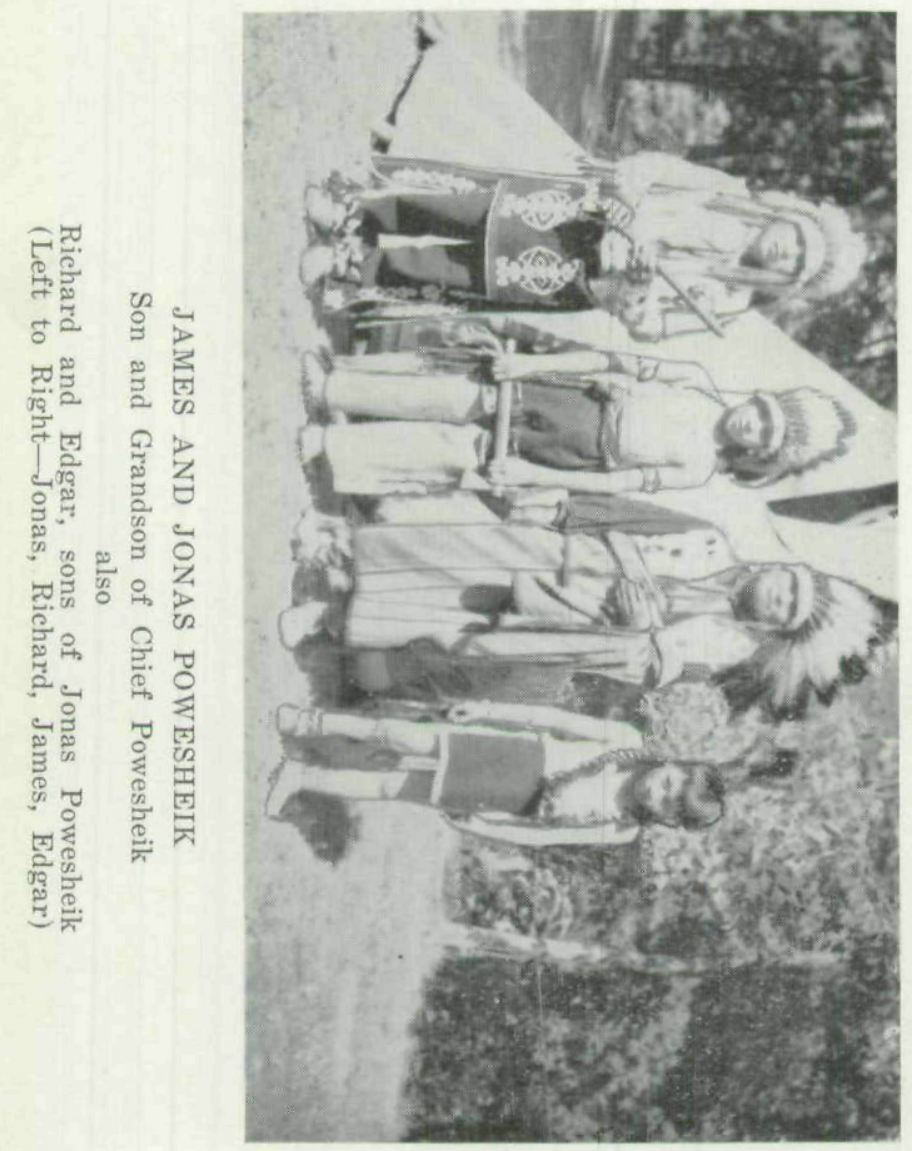


Chief Poweshiek came with others to Des Moines at the time of removal from Agency, and while Keokuk settled his Sac people along the Des Moines river south and east of the present city, Poweshiek located his camp west of the Des Moines river and near the new Fort Des Moines, including a large part of the present capital city of Iowa. The Foxes, under Poweshiek, went to the new lands in Kansas in 1843, 1844 and 1845. Some of them remained in southern Iowa for several years.

By the year 1853, the members of the Fox nation had become restive under the restraints at Quinamo, Kansas, as their reservation was called. The name meant "Lonesome Place" and that is the way they felt about it. This reservation was about six miles west of Ottawa, Kan. Those at Quinamo sent to Iowa a committee to arrange for return to their former home, and this committee purchased eighty acres on the Iowa river, which was expanded into their present farm of 3,600 acres. Chief Poweshiek had died in Kansas. The few Foxes who had remained in southern Iowa finally joined their brothers on the Iowa river in the county named for their former chief Ti-a-mah, or Tama.

It is recalled by the Mesquakie Indians that when the committee of head men had bargained for their first purchase of land in Iowa, they had only $\$ 750$ of the $\$ 1,000$ needed to complete the deal, and that they made up the balance by turning over their ponies. The committee on purchase consisted of the following: (1) Me she ne a, (2) Me te wega, (3) Ke me se a, (4) Be te ko to a, (5) Wa ko mi a.

One of the active members of the Fox nation who returned from the Lonesome Place in Kansas, was a resolute member of the Poweshiek family, a woman to whom was born on Sept. 16, 1854, soon after the return to Iowa, James Poweshiek, who has now lived nearly eighty-nine years as an honored member of the Mesquakie nation, as the Foxes call themselves. It is recalled by him that his mother, and others of the Foxes, came back from Kansas all the way walking and carrying 
all their worldly possessions. From their home in Tama county they made excursion to distant places, coming often to the Des Moines valley to hunt and fish and make sugar.

Jonas Poweshiek was born a son of James Poweshiek in 1896 and is now 47 years old. He is and has been for eighteen years employed by the Iowa State Department of History and Archives and has taken great pride in the splendid exhibit of Indian historical material owned by the state. On frequent occasions, Jonas and his family, have contributed in instructive manner to various celebrations and other events. On the occasion of the celebration of events at Black Hawk Park, near Rock Island, in 1940, he and his father and his two small sons, attended, and the picture accompanying this article was taken at that time showing the four in costume at the Black Hawk celebration. Those shown are Jonas, Richard, James and Edgar Poweshiek.

Jonas Poweshiek attended the great school at Carlisle, but before finishing he enlisted for World War I, and remained for the duration, in active service. There are four children in the family now. Jonas and two of the children attended the celebration ceremonies at the Des Moines city hall on May 20, 1943, and gave Indian songs and dances, and also they took part in the ceremonies at the monument marking the site of Fort Des Moines.

\section{THE KEOKUK PICTURES}

The Iowa State Department of History and Archives has two portraits of Chief Keokuk, the war chieftain of the Sacs and Foxes at the time Fort Des Moines No. 2 was established. One is a fine face view made from the photograph from which the picture in this issue is made; the other a copy of the famous painting by George Catlin, showing the chief mounted. 
Copyright of Annals of Iowa is the property of State of Iowa, by \& through the State Historical Society of Iowa and its content may not be copied or emailed to multiple sites or posted to a listserv without the copyright holder's express written permission. However, users may print, download, or email articles for individual use. 